\title{
MEMBANGUN QUALITY FUNCTION DEPLOYMENT UNTUK MENINGKATKAN KEPUASAN PASIEN PADA RUMAH SAKIT DI KOTA TEGAL
}

\author{
Makmur Sujarwo dan Subekti \\ Dosen FE Universitas Pancasakti Tegal \\ E-mail: makmursujarwo@gmail.com, subekti.ups@gmail.com
}

\begin{abstract}
This study aims to find out how far the Quality Function Deployment (QFD) strategy is built in hospitals in the city of Tegal so that it can improve patient satisfaction. This study uses a questionnaire distribution method with a sample of 120 hospital patients in the city of Tegal as respondents. Respondents' answers to closed questions about the variables examined in this study were then analyzed using Multiple Regression Tests with IBM SPSS Statistics 22 analysis. The results of this study indicate variebel tangibles and emphaty which have a positive and significant effect on increasing patient satisfaction with successive regression values according to 0.340 and 0.559 . For that reason, it has become a necessity for the hospital to further increase the tangible and empathetic of its patients in order to increase patient satisfaction. In the Quality Function Deployment (QFD) application, it shows that most of the requirements of patients (consumers) get value is very important and only a few who get important ratings, among others; rapid patient handling, the availability of sophisticated and modern hospital equipment technology; employees, nurses and doctors who are experts competent in their fields and friendly in serving patients, and others.
\end{abstract}

Keyword: Quality Function Deployment, tangibles, reliability, responsiveness, assurance dan emphathy.

\begin{abstract}
Abstrak-Penelitian ini bertujuan untuk mengetahui sejauh mana strategi Quality Function Deployment (QFD) dibangun di rumah sakit di kota Tegal sehingga dapat meningkatkan kepuasan pasien. Penelitian ini menggunakan metode distribusi kuesioner dengan sampel 120 pasien rumah sakit di kota Tegal sebagai responden. Responden terhadap pertanyaan tertutup tentang variabel dianalisis menggunakan Uji Regresi Berganda dengan analisis IBM SPSS Statistics 22. Hasil penelitian ini menunjukkan variableness dan empati yang memiliki pengaruh positif dan signifikan terhadap peningkatan kepuasan pasien dengan nilai regresi berturut-turut sesuai 0,340 dan 0,559. Oleh karena itu, menjadi lebih penting bagi pasien untuk meningkatkan kepuasan pasien. Dalam aplikasi Quality Function Deployment (QFD), itu menunjukkan kondisi yang paling penting bagi pasien (konsumen), antara lain; penanganan pasien yang cepat, ketersediaan teknologi peralatan rumah sakit yang canggih dan modern; karyawan, perawat dan dokter yang ahli dalam bidangnya dan ramah dalam melayani pasien, dan lainnya.
\end{abstract}

Kata Kunci: Quality Function Deployment, tangibles, reliability, responsiveness, assurance dan emphathy.

\section{PENDAHULUAN}

Tingkatpersainganantarrumahsakitdalam memperebutkan hati pasien mengharuskan pihak rumah sakit harus dapat meningkatkan kualitas pelayanannya. Pelayanan rumah sakit yang optimal akan berimplikasi terhadap peningkatan kepuasan pasien. Menurut Levitt (1987), syarat yang harus dipenuhi oleh suatu perusahaan agar dapat sukses dalam persaingan adalah berusaha mencapai tujuan untuk menciptakan dan mempertahankan pelanggan. Menurut Schnaars ( 1991), pada dasarnya tujuan dari suatu bisnis adalah untuk menciptakan para pelanggan yang merasa puas. Kotler,et al (1996) menandaskan bahwa kepuasan pelanggan adalah tingkat perasaan seseorang setelah membandingkan kinerja (atau hasil) yang ia rasakan dibandingkan dengan harapannya.

Rumah sakit sebagai tempat menyediakan dan memberikan pelayanan kesehatan yang meliputi berbagai masalah kesehatan ( KBBI offline), terus berupaya untuk memberikan pelayanan kesehatan kepada pasiennya. Pasien akan merasa puas jika hasil dari pelayanan kesehatan lebih tinggi dibandingkan harapannya. Hal ini tentu tidaklah mudah, karena pada dasarnya seorang pasien yang berobat ke Rumah sakit berharap mendapatkan kesembuhan dari penyakitnya. Selain itu pasien dan keluarga pasien juga 
memperoleh pelayanan yang optimal. Jika pasien mengeluh karena layanan rumah sakit, dan tidak tertangani keluhan tersebut secara tepat maka akan menyebabkan ketidakpuasan pasien terhadap layanan rumah sakit.

Menurut Fandy Tjiptono (2008) terdapat beberapa strategi yang dapat dipadukan untuk meraih dan meningkatkan kepuasan pelanggan,yaitu : strategi pemasaran berupa Relationship Marketing ( Mc Kenna ,1991), strategi superior customer service ( Schnaars,1991), strategi unconditional guarantees ( Hart,1988) atau extraordinary guarantees ( Hart dalam Supiyo,1993), strategi penanganan keluhan yang efisien ( Schnaars ,1991), strategi peningkatan kinerja perusahaan dan penerapan Quality Function Development (QFD).

Penelitian yang dilakukan Trisnawati, Nita (2011), tentang Analisis Kualitas Pelayanan Terhadap Kepuasan Pasien Instalasi RawatInap Dengan Gabungan Metode Servqual, Importance Performance Matrix Dan Kano Model Ke Dalam Quality Function Deployment menyimpulkan bahwa terdapat 20 respon teknis dengan urutan prioritas perbaikan yaitu pelatihan customer service excellent; penetapan standar ketepatan dan kecepatan waktu pelayanan; penambahan petugas dan sarana prasarana; Penambahan fasilitas pelayanan; penambahan fasilitas pendukung yang lengkap; penyempurnaan dan pengembangan SOP; penambahan fasilitas ruang kamar; penyemprotan serangga secara teratur; penambahan fasilitas medis kedokteran dan penunjang medis yang sesuai dengan kemajuan teknologi; penerapan pelayanan pasien tanpa membedakan status; menu makanan ditambah agar lebih bervariasi; penetapan dan pemberlakukan jadwal piket; melakukan pertemuan atau rapat komite medik secara teratur; penyesuaian biaya pengobatan; pemberian reward dan punishment; petugas keamanan melakukan patroli secara rutin; Pemasangan kamera CCTV; pengecekan jadwal pemeriksaan secara rutin; pengadaan kotak saran; perawatan fasilitas medis maupun non medis. Undergraduate thesis, Diponegoro University (2011).

Di kota Tegal terdapat beberapa rumah sakit, baik milik pemerintah maupun swasta. Bahkan saat ini ada rumah sakit di Kota Tegal yang telah mendapatkan Akreditasi
Paripurna dari Komite Akreditasi Rumah Sakit. Yang tentunya akan menambah daya saing antar rumah sakit di kota Tegal. Melihat tingkat persaingan antar rumah sakit di kota Tegal, peneliti merasa perlu untuk melakukan penelitian agar dapat diketahui sejauh mana rumah sakit di Kota Tegal telah mengimplementasikan strategi kepuasan pelanggan agar mereka dapat meningkatkan kepuasan pelanggan. Adapun strategi kepuasan pelanggan yang hendak diteliti adalah strategi Quality Function Deployment.

\section{Perumusan Masalah}

Maraknya tingkat persaingan Rumah Sakit, menjadi alasan perlu dilakukannya penelitian tentang sejauh mana rumah sakit-rumah sakit di kota Tegal telah mengimplementasikan strategi kepuasan pelanggan agar mereka dapat meningkatkan kepuasan pasiennya. Dengan latar belakang tersebut maka permasalahan-permasalahan yang ada atau dihadapi dapat dirumuskan, apakah strategi Quality Function Deployment ( QFD) melalui variabel tangibles, reliability, responsiveness, emphaty dan assurance,telah di implementasikan pada rumah sakitrumah sakit di Kota Tegal sehingga dapat meningkatkan kepuasan pelanggan?

\section{TUJUAN DAN MANFAAT PENELITIAN}

Penelitian ini bertujuan untuk mengetahui sejauh mana Quality Function Deployment ( QFD) telah di implementasikan pada rumah sakit-rumah sakit di Kota Tegal sehingga dapat meningkatkan kepuasan pelanggan. Penelitian ini diharapkan dapat memberikan kontribusi kepada pihak-pihak yang terkait, terutama bagi : bagi rumah sakit di kota Tegal, yaitu memberikan masukan bagi rumah sakit di Kota Tegal yang dapat berguna sebagai bahan pertimbangan dan pedoman dalam pengambilan strategi untuk memenangkan persaingan pasar. Adapun kontribusi bagi penelitian selanjutnya, sebagai pengetahuan mengenai sejauh manakah implementasi strategi kepuasan pelanggan pada rumah sakit di kota Tegal dan sebagai acuan referensi serta sebagai bahan penunjang untuk penelitian selanjutnya. 
TINJAUAN PUSTAKA DAN PENGEMBANGAN HIPOTESIS

\section{Kepuasan Pasien/ pelanggan}

Beberapa pakar yang mendefinisikan mengenai kepuasan/ketidakpuasan pelanggan. Wilkie ( 1990) mendefinisikan kepuasan pelanggan sebagai suatu tanggapan emosional pada evaluasi terhadap pengalaman konsumsi suatu produk atau jasa. Sementara Kotler, et al (1990) menyatakan bahwa kepuasan pelanggan adalah tingkat perasaan seseorang setelah membandingkan kinerja yang ia rasakan dibandingkan dengan harapannya. Sedangkan Pohan (2007) menyebutkan bahwa kepuasan pasien adalah tingkat perasaan pasien yang timbul sebagai akibat dari kinerja layanan kesehatan yang diperolehnya, setelah pasien membandingkan dengan apa yang diharapkannya. Pendapat lain dari Endang (dalam Mamik; 2010) bahwa kepuasan pasien merupakan evaluasi atau penilaian setelah memakai suatu pelayanan, bahwa pelayanan yang dipilh setidak-tidaknya memenuhi atau melebihi harapan.

Terdapat beberapa teori mengenai kepuasan. Teori yang menjelaskan apakah pasien sangat puas, puas, tidak puas adalah teoriperformasi yang diharapkan (expectationperformance theory) yang menyatakan bahwa kepuasan adalah fungsi dari harapan pasien tentang jasa dan performasi yang diterimanya. Jika jasa sesuai dengan harapannya ia akan puas; jika jasa kurang sesuai dengan yang diharap,ia akan merasa tidak puas. Kepuasan atau ketidak puasan pasien akan meningkat jika ada jarak yang lebar antara harapan dan kenyataan performasi pelayanan. Beberapa pasien cenderung memperkecil kesenjangan dan mereka akan terkurangi rasa ketidakpuasannya (Purnomo, 2002). Berdasarkan uraian dari beberapa ahli diatas, maka dapat disimpulkan bahwa kepuasan pelanggan mencakup perbedaan antara harapan dan kinerja atau hasil yang dirasakan.

\section{Faktor-faktor dalam mengevaluasi kepuasan pelanggan terhadap Jasa}

Menurut Parasuraman (1985) dalam mengevaluasi kepuasan pelanggan terhadap jasa, faktor-faktor yang digunakan adalah bukti langsung ( tangibles), keandalan ( reliability), daya tanggap ( responsiveness), jaminan (assurance) dan empati .

1. Bukti langsung (tangibles), meliputi fasilitas fisik, perlengkapan, pegawai, dan sarana komunikasi.

2. Keandalan ( reliability) merupakan kemampuan memberikan pelayanan yang dijanjikan dengan segera, akurat dan memuaskan.

3. Daya tanggap ( responsiveness) yaitu keinginan para staf dan karyawan untuk membantu para pelanggan dan memberikan pelayanan dengan tanggap

4. Jaminan ( assurance) mencakup pengetahuan, kemampuan, kesopanan, dan sifat dapat dipercaya yang dimiliki para staff; bebas dari bahaya, risiko atau keragu-raguan.

5. Empati meliputi kemudahan dalam melakukan hubungan, komunikasi yang baik, perhatian secara pribadi, dan memahami kebutuhan para pelanggan.

\section{Strategi Meningkatkan Kepuasan Pelanggan}

Menurut Fandy Tjiptono (2008) terdapat beberapa strategi yang dapat dipadukan untuk meraih dan meningkatkan kepuasan pelanggan yaitu : strategi pemasaran berupa Relationship Marketing, strategi superior customer service, strategi unconditional guarantees atau extraordinary guarantees, strategi penanganan keluhan yang efisien, strategi peningkatan kinerja perusahaan dan penerapan Quality Function Development (QFD).

\section{Strategi menerapkan Quality Function Deployment (QFD).}

Fokus utama QFD yaitu pelibatan konsumen pada proses pengembangan produk atau jasa sedini mungkin (Cohen,1995). Menurut Cohen, manfaat utama yang diperoleh dari penerapan QFD yaitu : rancangan produk dan jasa baru fokus pada kebutuhan pelanggan karena kebutuhan pelanggan tersebut sudah lebih dipahami, kegiatan desain dapat lebih diutamakan dan dipusatkan pada kebutuhan pelangggan, dapat menganalisis kinerja produk/jasa perusahaanterhadap pesaingutama dalam rangka memenuhi kebutuhan pelanggan utama pula, dapat memfokuskan pada upaya rancangan sehingga akan mengurangi 
waktu untuk perubahan rancangan secara keseluruhan sehingga akan mengurangi waktu pemasaran produk baru, dapat mengurangi frekuensi perubahan suatu desain setelah dikeluarkan dengan memfokuskan pada tahap perencanaan sehingga akan mengurangi biaya untuk memperkenalkan desain baru, dapat mendorong terselenggaranya tim kerja antar departemen, dan dapat menyediakan cara untuk membuat dokumentasi proses dan dasar yang kuat untuk pengambilan keputusan.

Penerapan QFD sebagai upaya mengindentifikasi keinginan dan kebutuhan pelanggan menggunakan format matriks yang disusun dalam suatu bentuk yang sering disebut dengan House of Quality (HoQ). Vita Pratama Sari, tentang Analisis Total Quality Service Dengan Penerapan Quality Function Deployment (Studi Pada PDAM Kota Surakarta) ;2010. Penelitian yang dilakukan Trisnawati, Nita (2011) tentang Analisis Kualitas Pelayanan Terhadap Kepuasan Pasien Instalasi RawatInap Dengan Gabungan Metode Servqual, Importance Performance Matrix Dan Kano Model Ke Dalam Quality Function Deployment menyimpulkan bahwa terdapat 20 respon teknis dengan urutan prioritas perbaikan yaitu pelatihan customer service excellent; penetapan standar ketepatan dan kecepatan waktu pelayanan; penambahan petugas dan sarana prasarana; Penambahan fasilitas pelayanan; penambahan fasilitas pendukung yang lengkap; penyempurnaan dan pengembangan SOP; penambahan fasilitas ruang kamar; penyemprotan serangga secara teratur; penambahan fasilitas medis kedokteran dan penunjang medis yang sesuai dengan kemajuan teknologi; penerapan pelayanan pasien tanpa membedakan status; menu makanan ditambah agar lebih bervariasi; penetapan dan pemberlakukan jadwal piket; melakukan pertemuan atau rapat komite medik secara teratur; penyesuaian biaya pengobatan; pemberian reward dan punishment; petugas keamanan melakukan patroli secara rutin; Pemasangan kamera CCTV; pengecekan jadwal pemeriksaan secara rutin; pengadaan kotak saran; perawatan fasilitas medis maupun non medis, Undergraduate thesis, Diponegoro University (2011).

Sementara penelitian yang dilakukan oleh Indrastuti, Nuri (2009) tentang Penerapan quality function deployment
(QFD) untuk pengembangan produk layanan ruang rawat inap anak di RSI Jakarta Pondok Kopi menyimpulkan bahwa prioritas pengembangan produk layanan ruang rawat inap anak RSIJPK yang dihasilkan malalui matriks QFD adalah: (1) adanya dukungan manajemen (2) petugas harus tanggap,cepat cermat dan ramah(3) kompetensi petugas diutamakan (4) SOP penerimaan pegawai perlu dirubah (5) penampilan petugas sesuai nuansa anak (6) Sarana dan prasarana ruang anak dikembangkan dan memenuhi stansar keselamatan untuk anak (7) Ruangan memiliki konsep yang mencerminkan ruangan anak (8) sumber dana ditingkatkan (9) kebijakan harus tegas (10) perlu layanan terpadu, Thesis,Perpustakaan Pusat UGM, 2009.

Penelitian yang dilakukan Diota, Kristanto Wahyu (2015) menyimpulkan Hasil perhitungan dan analisa QFD pada Rumah Sakit Banyumanik Semarang menunjukkan bahwa atribut jasa pelayanan yang dianggap penting oleh pasien berdasarkan tingkat kepentingan adalah menjaga kerahasiaan pasien selama berada dalam ruang rawat inap dengan nilai 3,564; berdasarkan urutan kinerja adalah menjaga kerahasiaan pasien selama berada dalam ruang rawat inap dengan nilai 4,25; berdasarkan nilai urutan prioritas adalah pelatihan perawat untuk pelayanan pasien dengan nilai 19,8650 .

Sedangkan penelitian yang dilakukan oleh Rahmatika, Dien Noviany (2000) tentang Evaluasi kualitas pelayanan rumah sakit dan penerapan konsep quality function deployment (Studi kasus pada rumah sakit umum daerah Brebes) dapat disimpulkan. Aplikasi QFD dengan menggunakan house of qualify menunjukkan hampir f seluruh persyaratan konsumen mendapat nilai penting dan sangat penting. Dan dari penjelasan teknis, kebijakan pendidikan dan pelatihan merupakan prioritas utama rumah sakit untuk menjawab kebutuhan dan persyaratan konsumen sehingga kepuasan konsumen bisa terpenuhi. Perpustakaan Pusat UGM, 2000.

\section{HIPOTESIS}

Proses evaluasi kepuasan pelanggan terhadap jasa menurut Parasuraman (1985) dipengaruhi oleh faktor-faktor antara lain bukti 
langsung (tangibles), keandalan (reliability), daya tanggap (responsiveness), jaminan (assurance) dan empati. Hal ini senada dengan penelitian yang dilakukan oleh Agung Utama tentang Analisis Pengaruh Persepsi Kualitas Pelayanan Terhadap Kepuasan Pelanggan Rumah Sakit Umum Cakra Husada Klaten, menunjukkan pelanggan (pasien) RSU Cakra Husada Klaten memiliki persepsi yang memuaskan atas kualitas pelayanan yang diterimanya (dirasakan) yang meliputi dimensi tangible, reliability,responsiveness, assurance, dan empath, (OPSI, Vol. 1, No. 2, Desember 2003: 96 - 110).

Sementara hasil penelitian yang dilakukan oleh Muh. Anwar Hafid (2014) dapat disimpulkan bahwa kinerja perawat mempunyai hubungan terhadap kepuasan pasien pengguna kartu yankestis dalam pelayanan keperawatan di RSUD Syech Yusuf kab. Gowa,(Jurnal Kesehatan :Volume VII No. 2/2014).

Dari beberapa kajian teori dan penelitian terdahulu diatas, Peneliti mengajukan beberapa hipotesis yaitu :

H1:Implementasi Quality Function Deployment dengan variabel tangibles berpengaruh positif terhadap peningkatan kepuasan pasien rumah sakit di Kota Tegal.
H2: Implementasi Quality Function Deployment dengan variabel reliability berpengaruh positif terhadap peningkatan kepuasan pasien rumah sakit di Kota Tegal.
H3:Implementasi Quality Function Deployment dengan variabel responsiveness berpengaruh positif terhadap peningkatan kepuasan pasien rumah sakit di Kota Tegal.

H4:Implementasi Quality Function Deployment dengan variabel emphaty berpengaruh positif terhadap peningkatan kepuasan pasien rumah sakit di Kota Tegal.

H5:Implementasi Quality Function Deployment dengan variabel assurance berpengaruh positif terhadap peningkatan kepuasan pasien untuk rumah sakit di Kota Tegal.

\section{Kerangka Pemikiran Teoritis}

Kerangka pemikiran teoritis ini menggambarkan adanya implementasi strategi penanganan keluhan yang efisien dan Quality Function Deployment dengan variabelvariabel tangibles, reliability, responsiveness, emphaty, dan assurance berpengaruh positif terhadap peningkatan kepuasan pelanggan untuk memenangkan pasar pada rumah sakit di Kota Tegal.

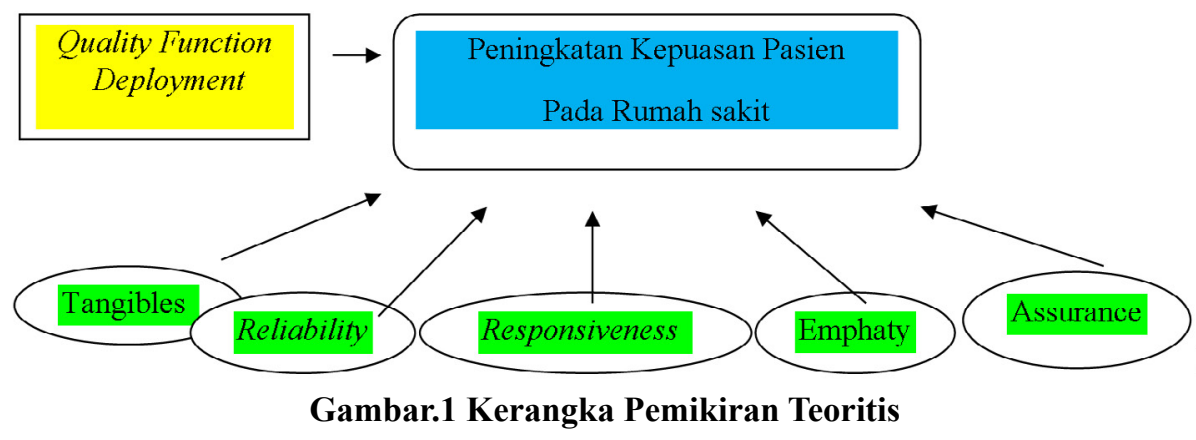

\section{METODE PENELITIAN}

\section{Jenis dan Sumber Data}

Data primer dalam penelitian ini diperoleh secara langsung dari pasien ( baik rawat inap maupun rawat jalan) sebagai responden yang ada di rumah sakit Kota Tegal.

\section{Populasi dan Sampel}

Dalam penelitian ini pengambilan sampel dilakukan dengan menggunakan jenis NonProbability Sample. Peneliti menggunakan non-probability sampling, karena beberapa alasan. Diantaranya karena murah dan digunakan bila populasi menyebar sangat luas sehingga cluster sampling menjadi tidak 
efisien.Adapun jenis non-probability sampling yang digunakan dengan purposive sampling.

Populasi yang digunakan dalam penelitian ini adalah rumah sakit yang ada di kota Tegal, yaitu RSUD Kardinah dan RSUI Harapan Anda. Menurut Gay dan Diehl (1992) pada kajian untuk kelas bisnis dan manajemen memberikan saran ukuran sampel minimal untuk penelitian korelasi, jumlah sampel minimum adalah 30 subjek. Dalam penelitian ini jumlah sampel yang diolah sebanyak 120 sampel dengan pasien dari beberapa rumah sakit tersebut sebagai responden.

\section{Metode Pengumpulan Data}

Metode pengumpulan data yang digunakan dalam penelitian ini adalah menggunakan kuesioner. Dengan kuesioner ini, responden diharapkan membaca dan menjawab pertanyaan yang diajukan oleh peneliti. Setelah itu, diharapkan langsung adanya tanggapan dari responden dan dapat langsung dikumpulkan oleh peneliti setelah mereka mengisinya. Pertanyaan-pertanyaan dalam kuesioner dibuat dengan menggunakan skala likert 5 poin (1: Sangat Tidak Setuju hingga 5 : Sangat Setuju).

\section{Teknik Analisis Data}

Teknik analisis yang digunakan dalam penelitian ini adalah menggunakan teknik analisis regresi untuk mengolah dan membahas data yang telah diperoleh dan unutk menguji hipotesis yang diajukan. Hair et al (1998) menyatakan bahwa regresi berganda merupakan teknik statistik yang menjelaskan keterkaitan antara variabel terikat dengan beberapa variable bebas. Regresi berganda juga dapat memperkirakan kemampuan prediksi dari serangkaian variabel bebas terhadap variabel terikat ( Hair et all, 1995). Berikut ini adalah persamaan regresi yang digunakan dalam penelitian ini :

$$
Y=a+b 1 X 1+b 2 X 2+b 3 X 3+\ldots . . b k X i k+e i
$$

Keterangan : Y : Kepuasan Pasien , $\mathrm{X} 1$ : Tangibles, $\mathrm{X} 2$ : Reliability , X3 : Responsiveness, X4: Assurance, X5 : Empathy, a : Konstanta , b 1, b2 : Koefisien Regresi, e : error

\section{Koefisien Determinasi $\left(\mathbf{R}^{2}\right)$}

Koefisien determinasi pada intinya mengukur seberapa jauh kemampuan model dalam menerangkan variasi variabel dependen. Nilai koefisien determinasi adalah antara nol dan satu. Nilai koefisien determinasi yang kecil berarti kemampuan variabelvariabel independent dalam menjelaskan variasi variabel dependen amat terbatas. Nilai yang mendekati satu berarti variabelvariabel independen memberikan hampir semua informasi yang dibutuhkan untuk memprediksi variasi variabel dependen. ( Ghozali ; 2011 : 97). Untuk menentukan nilai koefisien determinasi dinyatakan dengan nilai Adjusted $R$ Square. Adapun rumus koefisien determinasi adalah : R2 $=(\mathrm{r}) 2 \times 100 \%$ dimana : $\mathrm{R} 2=$ koefisien determinasi, $\mathrm{r}=$ koefisien korelasi

\section{Pengujian Hipotesa \\ Uji t (Uji Parsial)}

Uji t yaitu suatu uji untuk mengetahui pengaruh tangibles, reliability, responsiveness, assurance, empathy, dan responsiveness, terhadap peningkatan kepuasan pasien dalam memilih jasa rumah sakit di kota Tegal secara parsial.

\section{Uji F (Uji Simultan)}

Uji F yaitu suatu uji untuk mengetahui tangibles, reliability, responsiveness, assurance, dan empathy terhadap peningkatan kepuasan pasien dalam memilih jasa rumah sakit di kota Tegal secara simultan.

\section{Aplikasi Quality Function Deployment ( QFD)}

Fokus utama QFD yaitu pelibatan konsumen pada proses pengembangan produk atau jasa sedini mungkin (Cohen,1995). Aplikasi QFD dilakukan dengan melakukan 2 cara yaitu :

1. Mendefinisikan Persyaratan-persyaratan Pasien (Patient Requirements)

Langkah awal pada penerapan Quality Function Deployment adalah dengan menerapkan house of quality dengan cara mendefinisikan persyaratan-persyaratan pasien yang disyaratkan dalam pemilihan jasa/ layanan rumah sakit di kota Tegal. Persyaratan-persyaratan tersebut dikelompokkan dalam bentuk primary requirement, secondary requirement dan tertiery requirement. 
2. Memberikan Bobot atribut-atribut Patient Requirements

Bobot yang ada menunjukan tingkat kepentingan pada masing-masing patient requirements. Dengan menggunakan skala Likert dari 1-5, dengan penjelasan sebagai berikut : $1=$ STP : Sangat Tidak Penting, $2=$ TP: Tidak Penting, 3 $=\mathrm{N}$ : Netral, $4=\mathrm{P}$ : Penting dan $5=\mathrm{SP}$ : Sangat Penting.

\section{Dimensionalisasi Variabel}

1. Variabel Tangibles, terdiri dari dimensi variabel fasilitas fisik yang memadai ( indikatornya meliputi ; ruang kamar yang representatif sesuai dengan kelasnya, adanya tempat ibadah yang nyaman, dan adanya taman yang asri ), dimensi variabel perlengkapan ( indikatornya meliputi : ketersediaan alat-alat kesehatan yang representatif), dimensi variabel pegawai ( indikatornya meliputi ; perawat dan dokter yang ahli berkompeten di bidangnya dan ramah dalam melayani pasien dan karyawan yang ramah dalam melayani keluarga pasien) dan dimensi variabel sarana komunikasi ( indikatornya meliputi ; adanya call center, website, customer service departement yang menjadi pusat informasi pasien ).

2. Variabel Reliability terdiri dari dimensi variabel penanganan keluhan pasien dengan baik ( indikatornya meliputi ; pasien dapat segera teratasi keluhannya dengan baik), dimensi variabel pelayanan yang dijanjikan bersifat segera ( indikatornya meliputi ; penanganan masalah pasien cepat dan memuaskan) dan dimensi variabel penanganan pasien secara akurat ( indikatornya meliputi ; penanganan pasien dengan benar oleh petugas para medis).

3. Variabel Responsiveness terdiri dari dimensi variabel paramedis dan dokter membantu pasien dengan tanggap dengan indikatornya meliputi ; pasien dibantu dan dilayani oleh karyawan rumah sakit dengan tanggap, pelayanan administrasi yang tidak bertele-tele, petugas para medis dan dokter menangani pasien dengan cekatan.

4. Variabel Assurance terdiri dari dimensi variabel dokter, juru medis dan staff adalah para profesional dan berkompeten di bidangnya ( indikatornya adalah pasien terlayani secara profesional baik oleh dokter, juru medis maupun staff rumah sakit), dimensi variabel suasana yang nyaman bagi pasien dan keluarga pasien ( indikatornya berupa penataan ruang dan taman yang sesuai membuat pasien dan keluarga pasien merasakan kenyamanan) dan dimensi variabel komponen rumah sakit ramah dan sopan kepada pasien dan keluarganya ( indikatornya berupa keramahan dan kesopanan ditunjukkan dokter, para medis dan karyawan dalam menangani pasien )

5. Variabel Emphaty terdiri dari dimensi pihak rumah sakit memberikan kemudahan dalam komunikasi, perhatian secara pribadi, dan memahami kebutuhan para pelanggan dengan indikatornya meliputi ; dokter menjaga komunikasi dengan pasien secara baik, para medis dan staff rumah sakit senantiasa menjaga komunikasi dengan baik kepada pasien, pengaturan waktu periksa, pengaturan jadwal petugas jaga, Pengaturan jam kunjungan pasien dan kebutuhan pasien terlayani dengan baik.

6.

\section{HASIL PENELITIAN DAN PEMBA- HASAN}

Dari survey yang dilakukan, data terkumpul dan diolah dengan menggunakan IBM SPSS Statistics 22. Pada penelitian ini, obyek yang digunakan adalah para pasien baik pasien rawat jaga maupun pasien rawat inap ( sebagai responden ) yang ada pada rumah sakit- rumah sakit di kota Tegal. Peneliti menyebarkan kuesioner sebanyak 130 buah, dan kembali ke peneliti sebanyak 120 buah kuesioner. Kuisioner disebarkan pada pasienpasien pada rumah sakit-rumah sakit di kota Tegal. Survey telah dilaksanakan mulai 4 Juni hingga 30 Juli 2018.

\section{Hasil Uji Validitas}

Berdasarkan hasil Uji Validitas diketahui bahwa semua indikator adalah valid. Nilai korelasi dari masing-masing indikator dengan probabilitas korelasi [sig. (2-tailed)] sebesar 0,000 . Sesuai kriteria sebelumnya, maka semua indikator diatas adalah valid, karena 
nilai probabilitas korelasi [sig.(2-tailed) < dari taraf signifikan $(\alpha)$ sebesar 0,05 . Dengan demikian masing-masing indikator pada variabel tersebut dapat dilakukan kepada langkah penghitungan selanjutnya.

\section{Hasil Uji Reliabilitas}

Dari hasil uji reliabilitas, menunjukan bahwa nilai Cronbach Alpha sebesar 90,5\% yang menurut kriteria Nunnallly (1994) telah melebihi nilai $r$ tabel atau nilai Cronbach Alpha $>0.70$. Maka hasil data memiliki tingkat reliabilitas yang baik, atau dengan kata lain data hasil angket dapat dipercaya.

\section{Hasil Uji Multikoleniaritas}

Berdasarkan hasil uji multikolinearitas diatas menunjukkan bahwa nilai dari tolerance dan VIF untuk variabel Tangibles, Reliability, Responsiveness, Assurance, dan Emphaty menunjukkan nilai yang sama. Dari kriteria pengujian multikolonieritas menunjukkan bahwa semua nilai tolerance lebih besar dari nilai default yang ditentukan sebesar 0,10. Sedangkan untuk nilai VIF juga menunjukkan di bawah angka 10 . Sehingga dapat disimpulkan bahwa semua variabel telah memenuhi persyaratan ambang toleransi dan nilai VIF, artinya bahwa variabel bebas terhadap variabel terikat tidak terjadi multikolinieritas.

\section{Hasil Uji Normalitas}

Dari hasil uji normalitas dalam bentuk gambar histogram menunjukkan model regresi yang memiliki distribusi data normal atau mendekati normal.

\section{Uji Regresi Linear Berganda}

Dari olahan data menggunakan IBM SPSS Statistics 22, regresi linier berganda antara variabel Tangibles, Reliability, Responsiveness, Assurance, dan Emphaty untuk dapat meningkatkan kepuasan pasien pada rumah sakit di kota Tegal ( Y) dapat diperoleh hasil sebagai berikut :

$$
\begin{aligned}
& Y=0,950+0,340(X 1)+0,058(X 2)- \\
& 0,117(X 3)+0,217(X 4)+0,561(X 5)
\end{aligned}
$$

\section{Koefisien Determinasi ( $\mathbf{R}^{2}$ )}

Besarnya prosentase variabel peningkatan kepuasan pelanggan mampu dijelaskan oleh variabel bebas (koefisien determinasi) ditunjukkan dengan nilai Adjusted $R$ Square (R2) yaitu sebesar 0,147 menggunakan R2 karena variabel bebas dalam penelitian ini lebih dari satu, dalam hal ini dapat diartikan bahwa peningkatan kepuasan pasien pada rumah sakit dapat dijelaskan oleh variabel emphaty, visibility, accesibility, tangibles, responsiveness dan assurance dengan nilai sebesar $14,7 \%$, sedangkan sisanya dijelaskan oleh variabel lain yang tidak diteliti dalam penelitian ini.

\section{Hasil Pengujian Hipotesis}

\section{Hasil Pengujian Hipotesis Secara Parsial dengan Uji-t}

Hasil uji persial (uji t) yang dapat dijelaskan sebagai berikut :

a. Hipotesis 1 dengan Uji parsial ( uji-t ) menguji pengaruh tangibles terhadap peningkatan kepuasan pasien pada rumah sakit di kota Tegal menunjukkan hasil bahwa tangibles mempunyai pengaruh positif dan signifikan terhadap peningkatan kepuasan pasien rumah sakit di kota Tegal. Hal ini ditunjukkan oleh koefisien regresi sebesar 0,340 dan tingkat signifikansi sebesar $0,027<0,05$.

b. Hipotesis 2 dengan uji parsial ( uji-t) pengaruh reliability terhadap peningkatan kepuasan pasien pada rumah sakit di kota Tegal menunjukkan hasil bahwa reliability mempunyai pengaruh positif dan tidak signifikan terhadap peningkatan kepuasan pasien rumah sakit di kota Tegal. Hal ini ditunjukkan oleh koefisien regresi sebesar 0,058 dan tingkat signifikansi sebesar $0,755>0,05$.

c. Hipotesis 3 dengan uji parsial ( uji-t) pengaruh responsiveness terhadap peningkatan kepuasan pasien pada rumah sakit di kota Tegal menunjukkan hasil bahwa responsiveness mempunyai pengaruh negatif dan tidak signifikan terhadap peningkatan kepuasan pasien rumah sakit di kota Tegal. Hal ini ditunjukkan oleh koefisien regresi sebesar $-0,117$ dan tingkat 
signifikansi sebesar $0,478>0,05$.

d. Hipotesis 4 dengan uji parsial ( uji-t) menguji pengaruh assurance terhadap peningkatan kepuasan pasien pada rumah sakit di kota Tegal menunjukkan hasil bahwa assurance mempunyai pengaruh positif dan tidak signifikan terhadap peningkatan kepuasan pasien rumah sakit di kota Tegal. Hal ini ditunjukkan oleh koefisien regresi sebesar 0,021 dan tingkat signifikansi sebesar $0,900>0,05$.

e. Hipotesis 5 dengan uji parsial (uji-t) menguji pengaruh emphaty terhadap peningkatan kepuasan pasien pada rumah sakit di kota Tegal menunjukkan hasil bahwa emphaty mempunyai pengaruh positif dan signifikan terhadap peningkatan kepuasan pasien rumah sakit di kota Tegal. Hal ini ditunjukkan oleh koefisien regresi sebesar 0,561 dan tingkat signifikansi sebesar $0,002<$ 0,05 .

\section{Hasil Uji F (Uji Simultan)}

Dari uji Signifikansi Simultan ( Uji Statistik F) dapat diperoleh bahwa nilai F hitung sebesar 5.104 dengan sig. Sebesar 0.000 . Karena probabilitasnya $0.000<0.05$, maka model regresi tersebut dapat dikatakan bahwa tangibles, reliability, responsiveness, assurance dan emphaty secara bersama-sama berpengaruh terhadap peningkatan kepuasan pasien pada rumah sakit di kota Tegal. Maka hipotesis yang menyatakan ada pengaruh tangibles, reliability, responsiveness, assurance dan emphaty secara bersamasama berpengaruh secara simultan terhadap peningkatan kepuasan pasien diterima.

Dari hasil uji parsial maupun simultan diatas senada dengan penelitian yang dilakukan oleh Agung Utama tentang Analisis Pengaruh Persepsi Kualitas Pelayanan Terhadap Kepuasan Pelanggan Rumah Sakit Umum Cakra Husada Klaten, menunjukkan pelanggan (pasien) RSU Cakra Husada Klaten memiliki persepsi yang memuaskan atas kualitas pelayanan yang diterimanya (dirasakan) yang meliputi dimensi tangible, reliability,responsiveness, assurance, dan empath, (OPSI, Vol. 1, No. 2, Desember 2003: $96-110)$.

\section{Hasil Aplikasi Quality Function Deployment (QFD)}

a. Mendefinisikan Persyaratanpersyaratan Pasien ( Patient Requirements)

Berikut beberapa persyaratanpersyaratan yang dikelompokkan sesuai dengan jenis pelayanan jasa rumah sakit di kota Tegal dari primary requirements kemudian secondary requirements dan tertiary requirement sesuai dengan skala SERVQUAL. Penerapan QFD sebagai upaya mengindentifikasi keinginan dan kebutuhan pasien dengan menggunakan format matriks yang disusun dalam suatu bentuk yang sering disebut dengan House of Quality ( $\mathrm{HoQ}$ ).

Persyaratan-persayaratan pasien yang harus dipenuhi meliputi :

1) Primary Requirements yang terdiri atas : Tangibles, Reliability, Responsiveness, Assurance dan Emphaty

2) Secondary Requirements yang terdiri atas : fasilitas fisik yang memadai; perlengkapan, pegawai, sarana komunikasi, pelayanan yang dijanjikan bersifat segera ; penanganan pasien secara akurat, penanganan keluhan pasien dengan baik, paramedis dan dokter membantu pasien dengan tanggap ; dokter, juru medis dan staff adalah para profesional dan berkompeten di bidangnya ; suasana yang nyaman bagi pasien dan keluarga pasien ; komponen rumah sakit ramah dan sopan kepada pasien dan keluarganya ; pihak rumah sakit memberikan kemudahan dalam komunikasi, perhatian secara pribadi, dan memahami kebutuhan para pelanggan.

3) Tertiary Requirements yang terdiri atas : ruang kamar yang 
representatif sesuai dengan kelasnya, adanya tempat ibadah yang nyaman, adanya taman yang asri , ketersediaan alat-alat kesehatan yang representatif, perawat dan dokter yang ahli berkompeten di bidangnya dan ramah dalam melayani pasien dan karyawan yang ramah dalam melayani keluarga pasien, adanya call center, website, customer service departement yang menjadi pusat informasi pasien, pasien dapat segera teratasi keluhannya dengan baik, penanganan masalah pasien cepat dan memuaskan, penanganan pasien dengan benar oleh petugas para medis, pasien dibantu dan dilayani oleh karyawan rumah sakit dengan tanggap, pelayanan administrasi yang tidak bertele-tele, petugas para medis dan dokter menangani pasien dengan cekatan, pasien terlayani secara profesional baik oleh dokter, juru medis maupun staff rumah sakit, penataan ruang dan taman yang sesuai membuat pasien dan keluarga pasien merasakan kenyamanan ; keramahan dan kesopanan ditunjukkan dokter, para medis dan karyawan dalam menangani pasien ; dokter menjaga komunikasi dengan pasien secara baik, para medis dan staff rumah sakit senantiasa menjaga komunikasi dengan baik kepada pasien, pengaturan waktu periksa, pengaturan jadwal petugas jaga, Pengaturan jam kunjungan pasien dan kebutuhan pasien terlayani dengan baik.

\section{b. Bobot atribut-atribut Patient Requirements}

Bobot yang ada menunjukan tingkat kepentingan pada masing-masing patient requirements. Dengan menggunakan skala Likert dari 1 - 5, dengan penjelasan sebagai berikut : 1 = STP: Sangat Tidak Penting, $2=$ TP:
Tidak Penting, $3=\mathrm{N}$ : Netral, $4=\mathrm{P}$ : Penting dan 5= SP: Sangat Penting. Dari hasil pembobotan atribut patient requirements dapat diketahui bahwa pasien menginginkan beberapa penting pelayanan rumah sakit dapat dilakukan yang terbagi dalam :

1) Bobot 5, yaitu pelayanan rumah sakit yang sangat penting bagi pesien antara lain : penanganan pasien secara cepat, ruang ibadah yang representatif, alatalat kesehatan tersedia lengkap, tersedianya obat-obatan baik paten dan generik, tersedianya teknologi peralatan rumah sakit yang canggih dan modern, perawat dan dokter yang ahli berkompeten di bidangnya dan ramah dalam melayani pasien, karyawan yang ramah dalam melayani keluarga pasien, penanganan keluhan pasien dengan baik, penanganan masalah yang dihadapi pasien cepat dan memuaskan, penanganan pasien secara benar dilakukan oleh para petugas medis, pelayanan karyawan yang tanggap, pelayanan administrasi tidak bertele-tele, petugas para medis dan dokter menangani pasien dengan cekatan, pelayanan secara profesional baik oleh dokter, juru medis maupun karyawan , penataan ruang dan taman yang sesuai membuat pasien dan keluarga pasien merasakan kenyamanan, keramahan dan kesopanan ditunjukkan dokter, para medis dan karyawan dalam menangani pasien, komunikasi yang baik antara pasien dan dokter, juru medis serta staff di rumah sakit, pengaturan waktu periksa dan jadwal petugas jaga, pelayanan kebutuhan pasien dengan baik

2) Bobot 4, yaitu pelayanan rumah sakit yang penting bagi pasien antara lain : terdapat bagian Customer Service yang bertugas 
melayani pasien yang mendaftar untuk berobat, tersedianya call center sehingga dapat melakukan call setiap saat untuk mengetahui informasi tentang praktek dokter, ketersediaan kamar dll, tersedianya email, website rumah sakit sehingga memudahkan pasien dapat mengupdate informasi setiap saat, tersedianya kotak saran dan kritik sehingga pasien dapat memberikan saran dan kritik secara tertutup dan layanan mudah diakses oleh pasien

Dari hasil olahan data atribut persyaratan pasien ( patient requirements ) sebagian besar adalah sangat penting ( bobot 5) dan hanya sebagian kecil yang penting ( bobot 4 ). Kita dapat mengetahui bahwa atribut persyaratan pasien diatas sangat diperhatikan oleh pasien dalam memperoleh pelayanan jasa pada rumah sakit di kota Tegal.

Dari hasil olahan data aplikasi Quality Function Deployment diatas sejalan dengan penelitian terdahulu yang dilakukan oleh Indrastuti, Nuri (2009) tentang Penerapan quality function deployment (QFD) untuk pengembangan produk layanan ruang rawat inap anak di RSI Jakarta Pondok Kopi (Thesis,Perpustakaan Pusat UGM, 2009) , Vita Pratama Sari, tentang Analisis Total Quality Service Dengan Penerapan Quality Function Deployment (Studi Pada PDAM Kota Surakarta) ;2010dan Penelitian yang dilakukan Trisnawati, Nita (2011) tentang Analisis Kualitas Pelayanan Terhadap Kepuasan Pasien Instalasi RawatInap Dengan Gabungan Metode Servqual, Importance Performance Matrix Dan Kano Model Ke Dalam Quality Function Deployment.

\section{KESIMPULAN}

Penelitian ini menyimpulkan bahwa variabel tangibles, reliability, responsiveness, assurance dan emphaty secara bersama-sama berpengaruh terhadap peningkatan kepuasan pasien pada rumah sakit di kota Tegal. Sedangkan untuk pengujian secara parsial variabel reliability, assurance mempunyai pengaruh positif, tetapi tidak signifikan terhadap peningkatan kepuasan pasien pada rumah sakit di kota Tegal. Untuk pengujian parsial pada variabel responsiveness mempunyai pengaruh yang negatif dan tidak signifikan terhadap peningkatan kepuasan pasien pada rumah sakit di kota Tegal. Dan variabel tangibles dan emphaty mempunyai pengaruh positif dan signifikan terhadap peningkatan kepuasan pasien pada rumah sakit di kota Tegal. Dalam aplikasi Quality Function Deployment ( QFD ) data atribut persyaratan pasien ( patient requirements ) sebagian besar adalah sangat penting ( bobot 5) dan hanya sebagian kecil yang penting ( bobot 4 ). Kita dapat mengetahui bahwa atribut persyaratan pasien diatas sangat diperhatikan oleh pasien dalam memperoleh pelayanan jasa pada rumah sakit di kota Tegal.

\section{IMPLIKASI KEBIJAKAN DAN SARAN}

Berdasarkan atas temuan penelitian bahwa variabel tangibles dan emphaty yang berpengaruh signifikan terhadap peningkatan kepuasan pasien rumah sakit di kota Tegal, maka ada beberapa implikasi kebijakan sesuai dengan prioritas yang dapat diberikan sebagai masukan bagi Manajemen Rumah Sakit di Kota Tegal.

Adapun implikasi kebijakan manajerial yang disarankan adalah sebagai berikut $: 1$. Untuk variabel emphathy meliputi kemudahan dalam komunikasi, perhatian secara pribadi, dan memahami kebutuhan para pasien dengan indikatornya meliputi ; dokter menjaga komunikasi dengan pasien secara baik, para medis dan staff rumah sakit senantiasa menjaga komunikasi dengan baik kepada pasien, pengaturan waktu periksa, pengaturan jadwal petugas jaga, pengaturan jam kunjungan pasien dan kebutuhan pasien terlayani dengan baik. Maka untuk meningkatkan kualitas komunikasi, pihak manajemen rumah sakit hendaknya menerapkan kebijakan dengan mengadakan pelatihan Communication Skill 
bagi dokter, para medis maupun karyawannya. Adapun untuk pengaturan waktu periksa dan jadwal petugas, implikasi kebijakan yang harus diterapkan adalah dengan membuat jadwal paten dan terpampang jelas. 2 . untuk variabel tangibles, pihak rumah sakit hendaknya meningkatkan kualitas fasilitas fisik yang memadai seperti ruang kamar yang representatif sesuai dengan kelasnya, implikasi kebijakan manajerialnya adalah dengan membuat check list/daftar kamar yang di bersihkan beserta seluruh itemnya dan petugas yang mengerjakannya beserta pengawasnya. Selain itu pihak manajerial rumah sakit juga harus menydiakan sarana ibadah yang nyaman. Variabel tangibles lainnya juga harus ditingkatkan seperti ketersediaan alat-alat kesehatan yang representatif, implikasi kebijakan manajerialnya meliputi maintainance rutin yang harus dilakukan pihak-pihak terkait dan harus ada monitoring serta evaluasi terhadap umur pemakaian alat-alat kesehatan tersebut secara berkala. Kebijakan manajerial lainnya adalah pihak manajemen rumah sakit hendaknya menyediakan sarana call center, website, customer service departement yang menjadi pusat informasi pasien.

Saran untuk penelitian selanjutnya, agar lebih menambah jumlah responden dan juga cakupan wiayahnya. Hal ini dimaksudkan untuk menghindari subyektifitas pasien-pasien pada rumah sakit di kota Tegal dan sekitarnya.

\section{DAFTAR PUSTAKA}

Ghozali, I. 2001. Aplikasi Analisis Multivariate dengan SPSS. Badan Penerbit Universitas Diponegoro. Edisi 3. Semarang.

Ghozali, V.2011. Aplikasi Analisis Multivariate dengan Program IBM SPSS 19. Badan Penerbit Universitas Diponegoro. Edisi 5. Semarang.

Hafid, Muh. Anwar.2014, Jurnal Kesehatan : Volume VII No. 2/2014: Hubungan Kinerja Perawat Terhadap Tingkat Kepuasan Pasien Pengguna Yankestis dalam Pelayanan Keperawatan Di RSUD Syech Yusuf Kab.Gowa

Indrastuti, Nuri : 2009,Universitas Gadjah Mada : Penerapan quality function deployment (QFD) untuk pengembangan produk layanan ruang rawat inap anak di RSI Jakarta Pondok Kopi.

Indrawati, Ayu Desi.( 2013): Jurnal Manajemen, Strategi Bisnis, dan Kewirausahaan Vol. 7, No. 2, Agustus 2013 ; Pengaruh Kepuasan Kerja Terhadap Kinerja Karyawan dan Kepuasan pelanggan pada Rumah sakit Swasta Di Kota Denpasar.

Honny Nur Afidah ( 2013), Keefektifan Pelaksanaan Mekanisme Komplain dalam Pelayanan Kesehatan di Rumah Sakit Umum Haji Surabaya, Kebijakan Manajemen Publik,ISSN 2303 - 341X, Volume 1, Nomor 1, Tahun 2013

Indriantoro dan Supomo. 1999. Metodologi Penelitian Bisnis untuk Akuntansi dan Manajemen. Edisi Pertama. BPFE Yogyakarta. Yogyakarta.

Irawan, Andri (2016), http://ejournal.unmus.ac.id/index.php/societas,Volume 5 No 01 Tahun 2016.

Kotler, Philip dan Gary Armstrong ,2001, Prinsip-prinsip Pemasaran, Jilid1, Edisi Kedelapan, Jakarta, Erlangga.

Kotler, P.2002, Manajemen Pemasaran : Jakarta : PT Prenhalindo.

Nurul Afriani ( 2012), Analisis Penangan Keluhan Pelanggan oleh Instalasi Pemasaran dan Humas Rumah Sakit Umum Fatmawati 2012. Skripsi FKM UI,2012.

Tjiptono, Fandy (2008) : Strategi Pemasaran, Yogyakarta : ANDI 
Utama, Agung. ISSN 1693 - 2102 OPSI, Vol. 1, No. 2, Desember 2003: 96 - 110 : Analisis Pengaruh Persepsi Kualitas Pelayanan Terhadap KepuasanPelanggan Rumah Sakit Umum Cakra Husada Klaten. 